\title{
Trichoderma SPECIES DIVERSITY IN RHIZOSPHERE SOILS AND POTENTIAL ANTAGONISM WITH Fusarium oxysporum
}

\author{
DIVERSIDADE DE ESPÉCIES DE Trichoderma EM SOLOS DE RIZOSFERA E \\ POTENCIAL ANTAGONISMO COM Fusarium oxysporum
}

\author{
Laila NAHER $^{1,2}$; Nur SYAWANI $^{1}$; Nor AMIEZA $^{1}$; Afiqah Binti KAMARUDIN ${ }^{1}$; \\ S M R KARIM ${ }^{1}$ \\ 1. Faculty of Agro-Based Industry, Universiti Malaysia Kelantan, 17600, Jeli, Kelantan. lailanaher@umk.edu.my; 2. Institute of Food \\ Security and Sustainable Agriculture, Universiti Malaysia Kelantan, 17600, Jeli, Kelantan.
}

\begin{abstract}
In this study six different Trichoderma species were isolated form rhizosphere soils of paddy, banana, oil palm, rubber, vegetables and grass land soils. The species are T. harziaum, T. viride, T. koningii, T. asperrelum, and $T$. parareesei. The morphological study as pigmentation, colony growth and anatomical studies such as, conidiation appearances, size of conidia, conidiophores branching pattern, shapes of phialides, absent or present of chlamydiophores were carried out to identify the species of Trichoderma. The Trchoderma harzianum species were abundant in soil while T. viren was the second highest in the soil. All species showed the antagonistic activity against Fusarium oxysporum. While, $T$. parareesei showed the highest antagonistic $91.10 \%$ activity against $F$. oxysporum, reported as best antagonism agent for phytopathogen.
\end{abstract}

KEYWORDS: Antagonistic activity. Diversity. Fusarium oxysporum. Trichoderma.

\section{INTRODUCTION}

Fungi play the important roles in ecosystem and economic for development in nature. Decomposer for soil or disease causing in plant or animal fungi have numerous effect in both sectors. One of the most diverse groups of organisms on Earth is kingdom fungi because they are integral ecosystem agents that cycle soil carbon cycling and plant nutrition. Most of the fungi are entirely multicellular, heterotrophic and known as decomposers of nutrients (VERMA, 2012). Trichoderma is the genus of fungus that are economical important fungus as for decomposer in soil, celluloses or hemicellualases enzyme production for industrial, antibiotic production or act as biocontrol agent (SEKHAR et al., 2017). Trichoderma is soil borne fungus thus ubiquitous in all agricultural soil. As soil received the plant and animal residues, the soil microorganisms start to decompose the material. Trichoderma basically role as decomposer for cellulose, hemicellulose and chitin, however, the fungus also paly symbionts with plant and parasitic to other fungi (HARMAN, 2004). During the symbiotic situation, Trichoderma act as enhancer in plant in different sectors. Plant received advantages from Trichoderma, a) act as security that means protect plant form pathogenic fungi by direct encounter as Trichoderma grow towards the pathogenic fungus then coil around the it and kill the fungus or hydrolyse the fungus hypha (HARMAN et al., 2004), b) in direct protection
Trichoderma induced systemic resistance in plant, (HARMAN et al., 2004), and c) Trichoderma stay in root niche, the typical hyphal extension of Trichoderma tiger or stimulates the roots growth and bunches (HARMAN et al., 2004, NAHER et al., 2011). With this agreement found in oil palm plant which roots bunches were expand when oil palm treated with Trichoderma harziaum mulch compare to control plant (NAHER et al., 2012, 2014). LEE et al. (2016) reported that Trichoderma species produced volatile organic compounds in conjunction to enhance plant growth. In their study they found that Tomato biomass increased $>99 \%$, plant length and lateral roots also increased in corporation with Trichoderma viride treatment (LEE et al., 2016). Other than that, the presence of Trichoderma species in soil act as pesticides to kill the larvae and nematode in the soil. Trichoderma species penetrate the nematode body by forming haustoria like structure and colonize internally causing the death of nematodes (ZAIDI; SINGH, 2013). The role as fungicide the fungus control many phytopathogenic fungi of Rhizoctonia solani in potato plant, Ganoderma boninense in oil palm seedlings, Fusarium oxysporum in banana plant (NAHER et al., 2014; RAHMAN et al., 2014; ZHANG et al., 2014;). The role of Trichoderma as biofungicides and biofertilizer depends on the effectiveness of Trichoderma species. Thus, the isolation of Trichoderma species diversity is very importance. Hence, this research was conducted to identify the Trichoderma diversity in various rhizosphere soil to 
find the effective biocontrol agent against Fusarium oxysporum, a phytopathogen in several plant diseases.

\section{MATERIAL AND METHODS}

\section{Soil sample collection}

Rhizosphere soil samples were taken from different cultivated area as paddy, rubber, oil palm, banana plantation. The soil samples were collected at depth of $10 \mathrm{~cm}$ away from the surface and at the rhizosphere area. About 150 gram of soil for each site was taken by using soil auger, and then placed the soil into plastic zipper bag and kept in fridge at $4^{\circ} \mathrm{C}$ until used.

\section{Media preparation}

In this study two different medium as DRBA (Dichoran Rose Bengal Chloramphenicol) and PDA (Potato Dextrose Agar) media were used. DRBA media is good for soil fungal isolation (NAHER et al., 2016). While DPA was used for further culture process. A 19 gram of PDA powder and a 31.6 gram of DRBC were weighed and diluted in $500 \mathrm{ml}$ distilled water in conical flask in separately. Both conical flasks were stirred with hot plate for few minutes to dissolve the powder completely. Then, both medium was autoclaved at $121^{\circ} \mathrm{C}, 15$ psi for 15 minutes.

\section{Soil suspension and Soil serial dilution preparation}

Soil suspension prepared as $10 \mathrm{~g}$ of soil samples were dissolve in $100 \mathrm{ml}$ of sterilized distilled water and then mixed the composition using rotary shaker at $100 \mathrm{rpm}$ for 10 minutes. The soil suspension was used to prepare soil serial dilution to isolates the Trichoderma colony from soils. Serial dilutions were prepared as follows $1 \mathrm{ml}$ of soil suspension was added in $9 \mathrm{ml}$ of sterilized distilled water to make first dilution of $10^{1}$ from there subsequent dilutions prepared labelled as $10^{2}$, $10^{3}, 10^{4}$, and $10^{5}$.

\section{Soil culture}

Soil culture was performed to isolate the Trichoderma colony from soil. Under the sterile condition, $1 \mathrm{ml}$ of each dilution $\left(10^{1}, 10^{2}, 10^{3}, 10^{4}\right.$, and $10^{5}$ ) were pipetted into petri dish in separately followed with about $9 \mathrm{ml}$ DRBC agar solution was added into the plates in three replicates. The media was swirled gently to mix the solution and let it harden. After the media solidify, the plates was sealed with parafilm.

\section{Isolation of Trichoderma colony}

The diverse fungal growth on DRBA agar

plate was observed daily and calculated the colony formed. The visible fungal colonies formed were identified based on macromorphology characteristics as for primary selection of Trichoderma colony and then isolated into PDA media to obtain a pure culture.

\section{Slide culture observation}

A slide culture technique was done to identify the species of Trichoderma under light microscope. Under sterile condition, a sterile cotton swab and filter paper were placed in the petri dish and a microscopic slide was placed on cotton swab. Three to five drops of distilled water was dropped on the filter paper to keep the environment in the petri dish moisture for fungal growth. About $6 \mathrm{~mm}$ x $6 \mathrm{~mm}$ size of PDA agar was cut and placed at the centre on the microscopic slide. Four side of agar square were inoculated with spores of mycelia of fungus and cover with microscopic cover slit. The petri dish was covered and incubated at room temperature for two days to let the mycelia to grow.

\section{Identification of Trichoderma species}

Trichoderma species identification was carried out based on macro and micromorphological characteristics. For macromorphological characteristics colony growth, pigmentation. The micromorphology characteristic examination of fungus such as conidia, conidiophores, philiades, pigmentation and spore structure was identified under light microscope for identification key of Trichoderma species (GAMS; BISSETT, 2002). Identification key for Trichoderma species was used to compare and differentiate between species.

\section{Fusarium oxysporum culture}

The stock culture of Fusarium oxysporum was collected from tissue culture laboratory (UMK Jeli campus) which was isolated from banana plant in another study. The mycelial tips was transferred into a new PDA plate to obtain the pure culture of F. oxysporum.

\section{Antagonistic activity of Trichoderma isolates against $\boldsymbol{F}$. oxysporum}

An agar disc with diameter of $6 \mathrm{~mm}$ of newly grown pure culture Fusarium oxysporum was taken and placed from $1 \mathrm{~cm}$ of the petri dish wall. The plates was leaved for three days to growth of Fusarium oxysporum. Then Trichoderma species was introduced into the same plate but opposite site 
of the Fusarium oxysporum. Whereas, same technique was used for control plate but without received Trichoderma. The experiment was conducted in three replicates. All plates were left for 6 to 7 days to allow the colony grow. The linear growth and Percentage Inhibition of Radial Growth (PIRG) of Fusarium oxysporum was measured and calculated using formula by Kamala and Indera (2014) and descriptive assessment of antagonistic activity scaled by SOYTONG (1988).

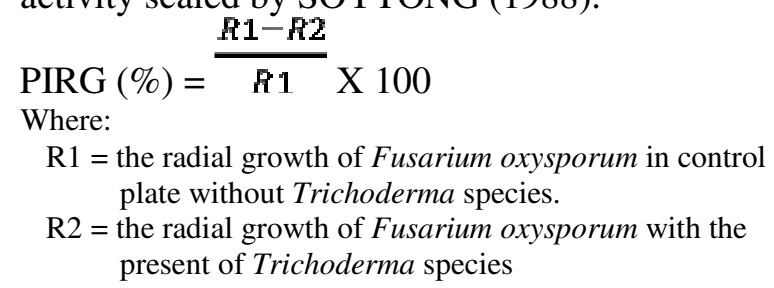

\section{Data collection}

The percentage of inhibition was considered as the antagonistic activity of Trichoderma species against Fusarium oxysporum. Data of PIRG was recorded during the 10 days of incubation period. The antifungal properties of Trichoderma strains considered as good bio control agent if the PIRG shows more than 50\% (RAHMAN et al., 2011).
NAHER, L. et al.

\section{RESULTS}

\section{Trichoderma isolation from soil}

A total of 355 diverse colonies were grown from the soil suspension culture. Based on the macro morphological characteristic of Trichoderma species, the pigmentation of colony was the primary selection for isolation of Trichoderma colony from soils. Trichoderma species had been found from all rhizosphere soil. The visible colonies on petri dish were identified based on its yellowish and greenish colour of mycelia on DRBC agar and 16 colonies of Trichoderma have been identified from the collected samples (Figure 1 and Table 1) in which three colonies were found from paddy field, one colony from rubber, two from scallion, two from oil palm plantation, two from eggplant, two mugbean, two colonies from tomato cultivated soil, one from pineapple cultivated soil, and one colony banana plantation shown in Table 1 and Figure 1. The colonies were subculture on PDA media for pure culture preparation and identification of Trichoderm species.

Table 1. Colony, dilution, origin and isolation code of Trichoderma from soil culture

\begin{tabular}{llll} 
Trichoderma colony & Dilution & Origin of Trichoderma & Code \\
Colony 1 & $1 \times 10^{-1}$ & Rhizosphere of Paddy & P1 \\
Colony 2 & $1 \times 10^{-2}$ & Rhizosphere of Paddy & P2 \\
Colony 3 & $1 \times 10^{-2}$ & Rhizosphere of Paddy & P3 \\
Colony 4 & $1 \times 10^{-2}$ & Rhizosphere of Long Bean & LB4 \\
Colony 5 & $1 \times 10^{-2}$ & Rhizosphere of Long Bean & LB5 \\
Colony 6 & $1 \times 10^{-1}$ & Rhizosphere of Eggplant & E6 \\
Colony 7 & $1 \times 10^{-1}$ & Rhizosphere of Eggplant & E7 \\
Colony 8 & $1 \times 10^{-1}$ & Rhizosphere Scallion & S8 \\
Colony 9 & $1 \times 10^{-1}$ & Rhizosphere Scallion & S9 \\
Colony 10 & $1 \times 10^{-1}$ & Rhizosphere of Oil palm & OP10 \\
Colony 11 & $1 \times 10^{-1}$ & Rhizosphere of Oil palm & OP11 \\
Colony 12 & $1 \times 10^{-4}$ & Rhizosphere of Pineapple & P12 \\
Colony 13 & $1 \times 10^{-3}$ & Rhizosphere of Rubber & R13 \\
Colony 14 & $1 \times 10^{-1}$ & Rhizosphere of Banana & B14 \\
Colony 15 & $1 \times 10^{-3}$ & Rhizosphere of Tomato & T15 \\
Colony 16 & $1 \times 10^{-3}$ & Rhizosphere of Tomato & T16 \\
\hline
\end{tabular}



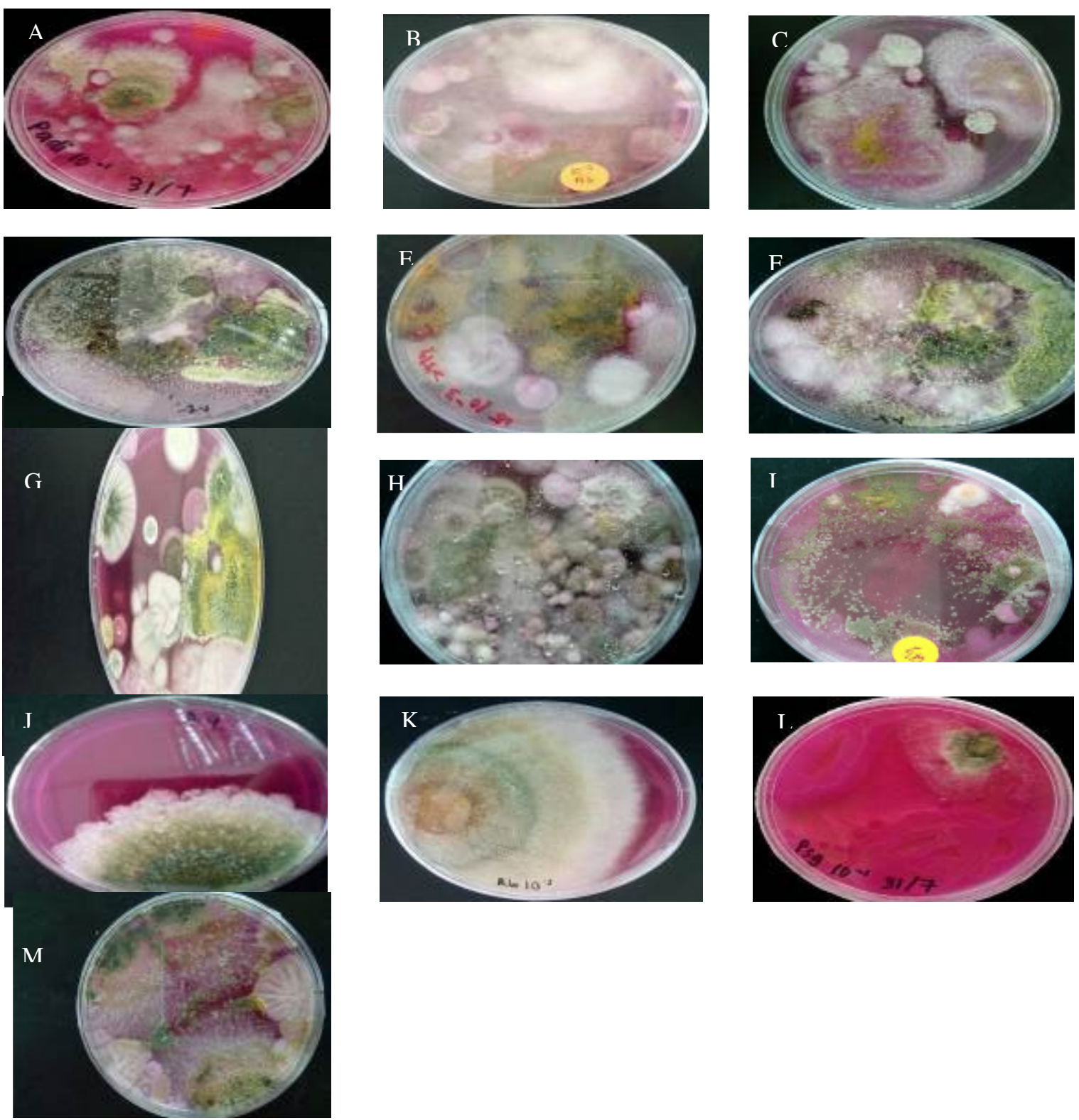

Figure 1. Isolation of Trichoderma colonies from soil grown on DRBC media. The rhizosphere soil were; A\& B: paddy C\&D: Long bean; E: Eggplant; F\&G: Scallion; H\&I: Oil palm; J: Pinneaple; K\&L: Rubber and M: tomato.

\section{Pure culture of Trichoderma colonies on PDA media}

The selected colonies on DRBC agar plates were sub-culture on PDA plate for identification of isolates of Trichoderma species. Based on the physical observation on PDA plate, Trichoderma species had an irregular form, flat elevation and undulate margin which makes them different from other fungi colony (Figure 1). Other than that, Trichoderma has greenish or yellowish- green colony. The formation of the colonies was faster where they took less than five days to fully colonize the media plate. The greenish or yellowish-green colour usually on three to four days after growth. The reverse color appears when the Trichoderma species are fully matured and become whitish, pale green or tan and sometimes can be yellow (GAMS; BISSETT, 2002). Hence, these physical observation characterise as macro-morphological feature of Trichoderma species. Meanwhile, the slide cultures were carried out on microscopic characterization for identification of Trichoderma species. The characteristics of isolated Trichoderma species have been summarized in Table 2 . 
Table2. Micro- and macromorphological characteristics of Trichoderma isolates

\begin{tabular}{|c|c|c|c|c|c|c|}
\hline \multirow[b]{2}{*}{ Characters } & \multicolumn{6}{|c|}{ Isolates } \\
\hline & $\begin{array}{l}\text { P1\&P2, } \\
\text { S8\&9,LB4,5, } \\
\text { B14, T15,\&16 }\end{array}$ & P3 & E6\&7 & $\begin{array}{l}\text { OP10, } \\
\text { R13 }\end{array}$ & OP11 & P12 \\
\hline Colony growth & $\begin{array}{l}\text { Faster } \\
\text { growth } \\
\quad(0.7 \mathrm{~cm} / \mathrm{d})\end{array}$ & $\begin{array}{l}\text { Moderat } \\
\text { e growth } \\
(0.5 \mathrm{~cm} / \mathrm{d})\end{array}$ & $\begin{array}{l}\text { Moderate } \\
\text { growth } \\
(0.6 \mathrm{~cm} / \mathrm{d})\end{array}$ & $\begin{array}{l}\text { Moderate } \\
\text { growth } \\
(0.6 \mathrm{~cm} / \mathrm{d})\end{array}$ & $\begin{array}{l}\text { Rapid } \\
\text { growth } \\
(0.9 \mathrm{~cm} / \mathrm{d})\end{array}$ & $\begin{array}{l}\text { Moderate } \\
\text { growth } \\
(0.6 \mathrm{~cm} / \mathrm{d})\end{array}$ \\
\hline Colony colour & $\begin{array}{l}\quad \text { Dark } \\
\text { green to } \\
\text { yellowish } \\
\text { green with } \\
\text { dense white } \\
\text { mycelia } \\
\text { pustulates }\end{array}$ & $\begin{array}{l}\quad \text { Dark } \\
\text { green with } \\
\text { few white } \\
\text { aerial } \\
\text { mycellia }\end{array}$ & $\begin{array}{l}\text { Yellowish- } \\
\text { white to dull } \\
\text { green }\end{array}$ & $\begin{array}{l}\text { Yellowis } \\
\text { h-white } \\
\text { to dull } \\
\text { green }\end{array}$ & $\begin{array}{l}\text { Blue green } \\
\text { to } \\
\text { yellowish } \\
\text { green }\end{array}$ & $\begin{array}{l}\text { Dark green } \\
\text { with dense } \\
\text { white } \\
\text { mycelia } \\
\text { pustulates }\end{array}$ \\
\hline Conidiophore & $\begin{array}{l}\text { Broad, } \\
\text { verticillate, } \\
\text { frequent } \\
\text { branching. } \\
\text { Short branches } \\
\text { phialides }\end{array}$ & $\begin{array}{l}\quad \text { A central } \\
\text { stripes with } \\
\text { symmetricall } \\
\text { y paired } \\
\text { branches. } \\
\text { The second } \\
\text { branch were } \\
\text { observed but } \\
\text { not for third } \\
\text { branches }\end{array}$ & $\begin{array}{l}\text { Narrow } \\
\text { branching. } \\
\text { The branches } \\
\text { arise at pairs } \\
\text { with the } \\
\text { terminal } \\
\text { conidiophores } \\
\text { are longer } \\
\text { than other. }\end{array}$ & $\begin{array}{l}\text { The base } \\
\text { of } \\
\text { conidiop } \\
\text { hores are } \\
\text { sterile } \\
\text { and have } \\
\text { no } \\
\text { branches } \\
\text { but fertile } \\
\text { at apices }\end{array}$ & $\begin{array}{l}\text { Variables, } \\
\text { Branched } \\
\text { and erects }\end{array}$ & $\begin{array}{l}\text { Narrow and } \\
\text { flexuous }\end{array}$ \\
\hline Phialides & $\begin{array}{l}3 \text { to } 4 \\
\text { phialides in } \\
\text { whorls. } \\
\text { Ampuliform } \\
\text { and } \\
\text { lageniform } \\
\text { forming at } \\
\text { dense area }\end{array}$ & $\begin{array}{l}\text { Paired } \\
\text { primary } \\
\text { branches } \\
\text { formed in } \\
\text { nearly } 90^{\circ} \text { to } \\
\text { main axis, } \\
\text { phialides } \\
\text { may be } \\
\text { solitary or } \\
\text { held in } \\
\text { whorls of } \\
\text { two to three. } \\
\text { Langeniform } \\
\text { in effuse } \\
\text { area and } \\
\text { ampuliform } \\
\text { at dense } \\
\text { area. }\end{array}$ & $\begin{array}{l}2 \text { to } 3 \text { phialides } \\
\text { in with closely } \\
\text { lageniform to } \\
\text { subulate } \\
\text { divergent } \\
\text { phialides. }\end{array}$ & $\begin{array}{l}3 \text { to } 6 \\
\text { phialides } \\
\text { in with } \\
\text { closely } \\
\text { appressed } \\
\text { which } \\
\text { only } \\
\text { form at } \\
\text { apices of } \\
\text { branches. } \\
\text { Most } \\
\text { phialides } \\
\text { were } \\
\text { ampulifor } \\
\text { m and } \\
\text { langenifo } \\
\text { rm. }\end{array}$ & $\begin{array}{l}\text { Pair } \\
\text { phialides. } \\
\text { Lagenifor } \\
\text { m; more or } \\
\text { less } \\
\text { ampullifor } \\
\text { m }\end{array}$ & $\begin{array}{l}\text { Solitary, } \\
\text { verticillate, } \\
\text { more / less } \\
\text { lageniform }\end{array}$ \\
\hline Conidia & $\begin{array}{l}\text { Subglobose } \\
\text { green, smooth } \\
\text { conidia }\end{array}$ & $\begin{array}{l}\text { Globose, } \\
\text { obovoid } \\
\text { dark green, } \\
\text { smooth } \\
\text { conidia }\end{array}$ & $\begin{array}{l}\text { Subglobose to } \\
\text { ellipsoid }\end{array}$ & $\begin{array}{l}\text { Subglobo } \\
\text { se, } \\
\text { ellipsoid } \\
\text { dark } \\
\text { green }\end{array}$ & $\begin{array}{l}\text { Slight } \\
\text { cylindrical } \\
\text { and } \\
\text { abundant }\end{array}$ & Subglobose \\
\hline $\begin{array}{l}\text { Chlamydospho } \\
\text { re }\end{array}$ & Present & Present & Not observed & Present & Present & Present \\
\hline Species & T.harzianum & T.asperellum & T.pararesei & T.virens & T.koningii & T.viride \\
\hline New coded & $\begin{array}{l}\text { THP1, THP2, } \\
\text { THS8, THS9, } \\
\text { THLB4, } \\
\text { THLB5, } \\
\text { THB14, } \\
\text { THT15 \& } \\
\text { THT16 }\end{array}$ & TAP3 & TPE6 \&TPE7 & $\begin{array}{l}\text { TVOP10, } \\
\text { TVR13 }\end{array}$ & THOP11 & TVP12 \\
\hline
\end{tabular}




\section{Trichoderma harzianum}

The colonies of Trichoderma harzianum were initially formed white mycelia which then changed into yellowish green or dark green on the progression of its maturation and spreading. As for growth, the fungus showed faster growth $0.7 \mathrm{~cm}$ per day (Table 2). Due to the faster colonization of mycelia, formation of white aerial mycelia and green colour colony, the characteristics made the species was easier to be identified. Conidiophores of Trichoderma harzianum were formed in paired along the main branches and axis (Figure 3; A-C). The conidiophores branching patterns was broad, verticillate, and frequent branching with a degree of $90^{\circ}$ (Figure 3C) One branching verticillate usually had three to four of phialides (Figure $3 \mathrm{~B}$ ). Phialides were characteristically elongate and lageniform in shapes (Figure 3; A-B). At the end of phialides or subterminal cell of conidiophores, conidia were formed with a shape of globose (Figure 3D and 3F) to subglobose (Figure 3E). The chlamydospores were observed to have globose (figure $3 \mathrm{H}$ ) to subglobose shapes (Figure $3 \mathrm{G}$ and 3I). The full growth with conidiation shown in figure $3 ; \mathrm{J}-\mathrm{L}$. From the observation, the isolates of PDY 1,2; $\mathrm{S}$ 8,9; LB4,5; T15,16 and B14 were identified to belong Trichoderma harzianum species and all the isolate later coded as THP1, THP2, THS8, THS9, THLB4, THT15, THT16 and THB14, respectively (Table 2).
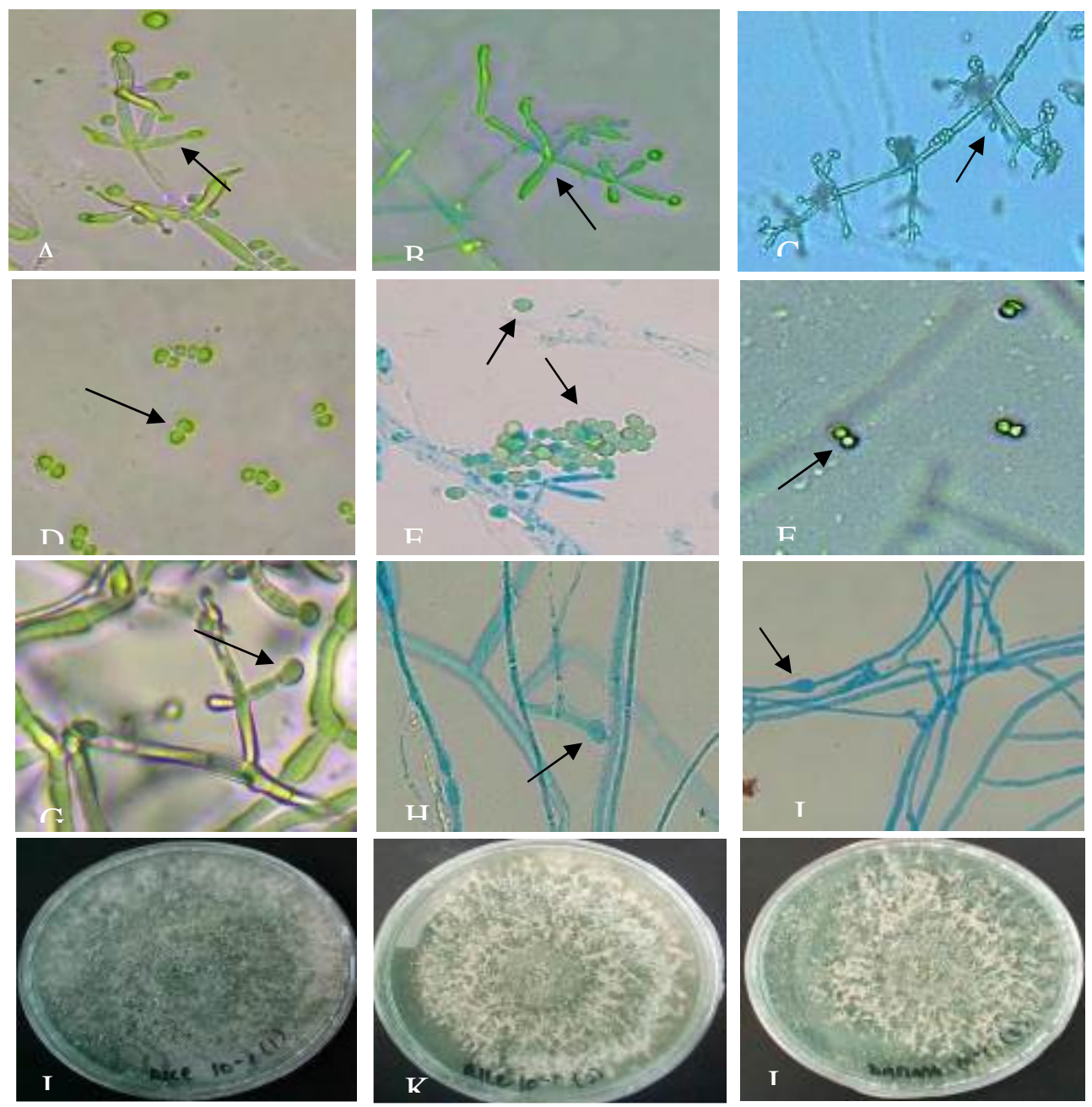

Figure 3. Microscopic morphological characteristic of T.harzianum in isolated colonies $\mathrm{P} 1,2 ; \mathrm{S} 8,9 ; \mathrm{LB} 4,5 ; \mathrm{T}$ 15,16 and B14 (THP1, THP2, THS8, THS9, THLB4, THT15, THT16 and THB14). A-C: phialides held in whorl of three to four with the shapes of langeniform (arrow), D-F: globose,subglobose and subcylindrical conidia (arrow), G-I: globose to subglobose chlamydospores (arrow), J-L: conidiation of Trichoderma harzianum. (Under microscope Leica: 40X)

\section{Trichoderma asperellum}

The colony of $\mathrm{P} 3$ was shown the feature of T. asperellum. As the fungal growth was moderate
$0.5 \mathrm{~cm} /$ day (Table 2). The colony of T.asperellum forms less white pustules mycelium compare to $T$. harzianum (Figure 4i). The conidiation was 
predominantly effused and powdery. Most of the conidiophores of $T$. asperellum were formed symmetrically paired along the main branches and axis (Figure $4 \mathrm{c}$ ). The conidiophores branching patterns was broad, verticillate, and almost $90^{\circ}$ angle (Figure 4d (2)). One branching verticillate usually had two to four of phialides (Figure 4;a-d). The second branch were observed but not for the third branches (Figure 4e). Phialides were characteristically elongate divergent lageniform (Figure 4e) and can be ampuliform in dense area (Figure 4e) in shapes. The terminal phialides were usually more elongated than another side of phialides (Figure $4 \mathrm{~b}$ and $\mathrm{d}$ (1)). The special shapes of terminal phialides were used to differentiate between $T$. harzianum with $T$. asperellum in this study. At the end of phialides or subterminal cell of conidiophores, conidia were formed with a shape of globose (Figure $4 \mathrm{f}(2)$ ) to obovoid (Figure $4 \mathrm{f}$ (1)). Meanwhile, the conidia colour showed dark green under a light microscope. The formation of chlamydospores was observed to have subglobose (Figure $4 \mathrm{~g}$ ) and globose (Figure $4 \mathrm{~h}$ ). They mostly found in the middle of hyphae (Figure $4 \mathrm{~g}-\mathrm{h}$ ). Based on the characteristic stated above, the isolates of $\mathrm{P}$ was identified to belong in Trichoderma asperellum and later coded as TAP3 (Table2)
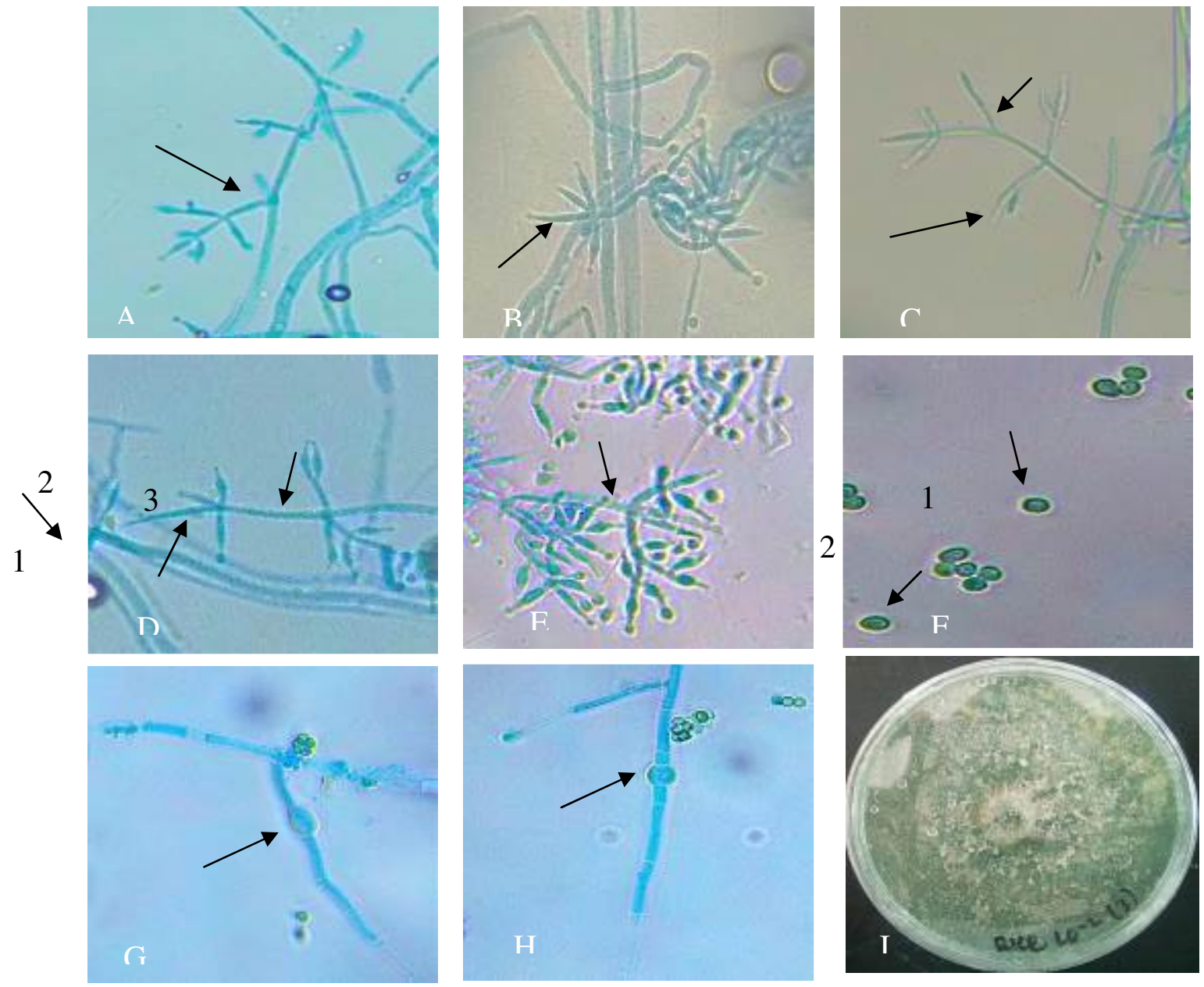

Figure 4. Morphological characteristic of Trichoderma asperellum in isolated colony P3 (TAP3). A: unpaired branch (arrows), B-C: Two to four phialides held in paired and unpaired with subulate shapes of phialides (arrow), D1and D2: The terminal phialides was longer than other phialides (arrow), D 3: Conidiophores broad branching pattern with $90^{\circ}$ (arrow), F (1-2): Obovoid to globose conidia with dark green (arrow), G-H: Subglobose to globose chlamydospores (arrow), I: Conidiation of Trichoderma asperellum on PDA plate. (Under microscope Leica: 40X).

\section{Trichoderma virens}

The isolates OP10 and R13 feature were $T$. virens similarity. The anatomical studies on conidiophores formed were many branches (Figure
5B) with aggregate phialides at the end of conidiophores (figure 5A). The branches were mostly unpaired and smoothly bending (Figure 5C). The base of conidiophores was sterile and have no 
branches while fertile at the apex towards phialides (figure 5B). The phialides were not spreading but closely packed together forming like a cluster of slender phialides. There were about 3 to 6 phialides in closely appressed (Figure 5D) while the philiadosphores forming abundantly at the apices. The phialides were lageniform to subulate in shape (figure 5; C-D). The conidia were globose to ovoid in shape and the conidia colour was bluish green
(Figure 5; E-F). The formation of chlamydospores was rare and difficult to observe. The chlamydospores were identified to form subglobose in shape (Figure 5; G-H) and can be found in the middle of branches (Figure 5G) or at the end of hyphae (Figure $5 \mathrm{H}$ ). Based on the characteristic stated, isolates of OP10 and R13 identified to belong in Trichoderma virens which coded as TVOP10 and TVR13 (Table 2).
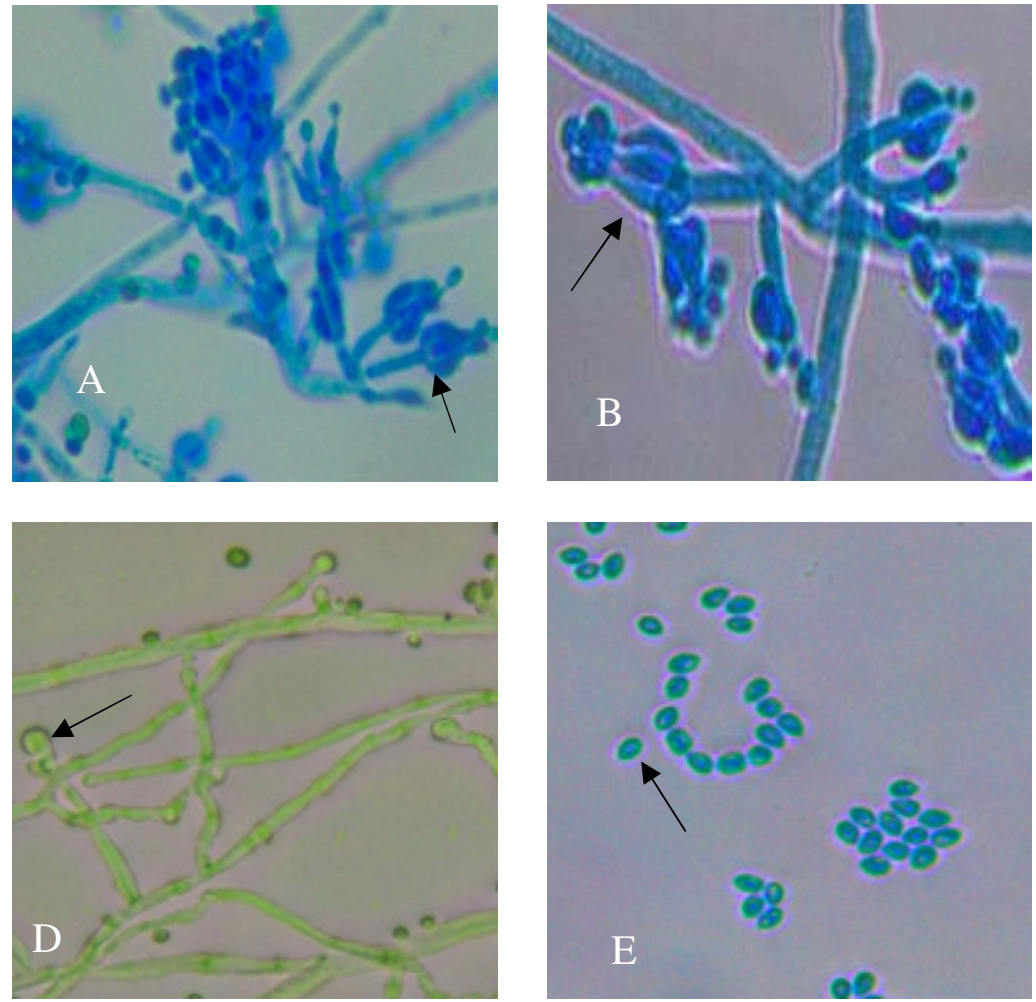
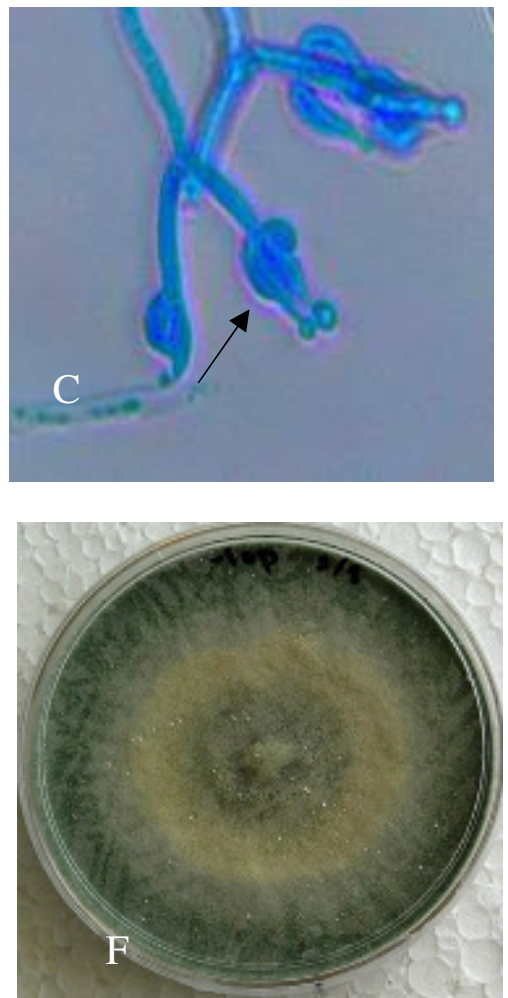

Figure 5. Morphological characteristics of T. virens isolated colony 3(TVOP10, TVR13). A-C: The Phialides and the branches of conidiophores (arrows); D: Chlamydospores (arrows); E: Phialospores (arrow). F: Conidiation of Trichoderma virens on PDA plate. (Under microscope Leica: 40X).

\section{Trichoderma koningii}

The isolated colony OP11 macromophological and micro-morphological feature showed as T. koningii. The micro-morphological studies on conidiophores were paired primary branches which were usually formed in nearly $90^{\circ}$ to the main axis and phialides tend to be cylindrical to sharply constrict at the tips (Figure 6; A-C). Most of the chlamydospores in other isolates were formed on the hyphal tips. However, in T. koningii the chlamydospores were found within the hyphae (Figure 6D). The phialospore showed as subcylindrical to narrow ellipsoid in T. koningi $(6 \mathrm{E})$. Based on these characteristics the colony OP11 belongs to Trichoderma koningii which coded as TKOP11 (Table2).

\section{Trichoderma viride}

The isolated colony OP11 on macromorphological and micro-morphological feature showed as $T$. viride. The features on conidiophores showed as long, straight, solitary and fertile apices (Figure 7; A to C). In this study all Trichoderma isolates were found to produce chlamydospores after 7 days. In colony OP11 the chlamydospores observed as unicellular and appeared globose to subglobose (Figure 7D). Most of the chlamydospores were formed on the hyphal tips. The phialospores of were subglobose to obovoid or ellipsoid (Figure 7E). Based on there morphological characteristics the colony OP11 identified as Trichoderma viride and coded as TVOP11 (Table 2). 

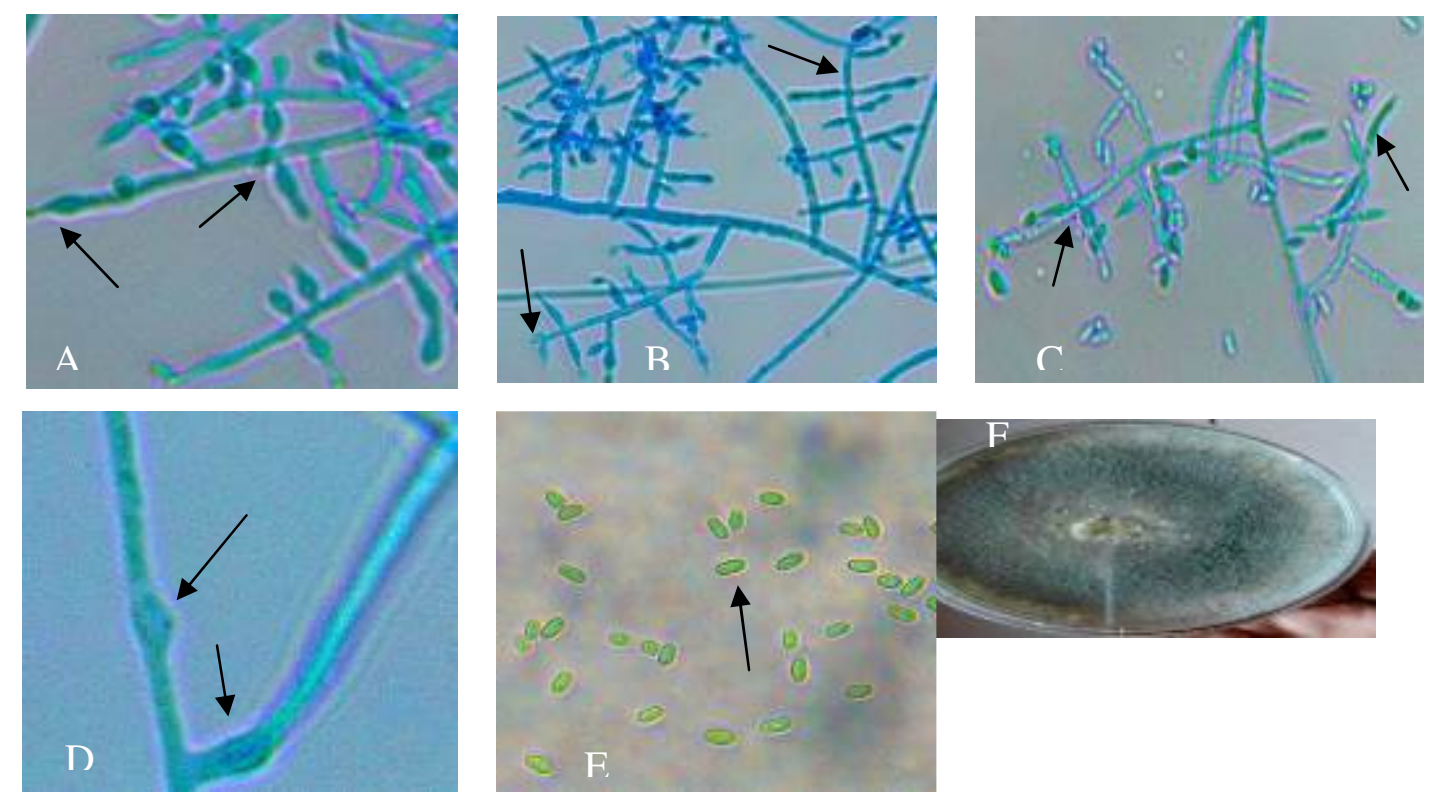

Figure 6. Morphological characteristics of T. koningii in isolated colony OP11 (TKOP11). A-C: The Phialides and the branches of conidiophores (arrows); D: Chlamydospores (arrows); E: Phialospores (arrow). F: Conidiation of Trichoderma koningii on PDA plate. (Under microscope Leica: 40X).
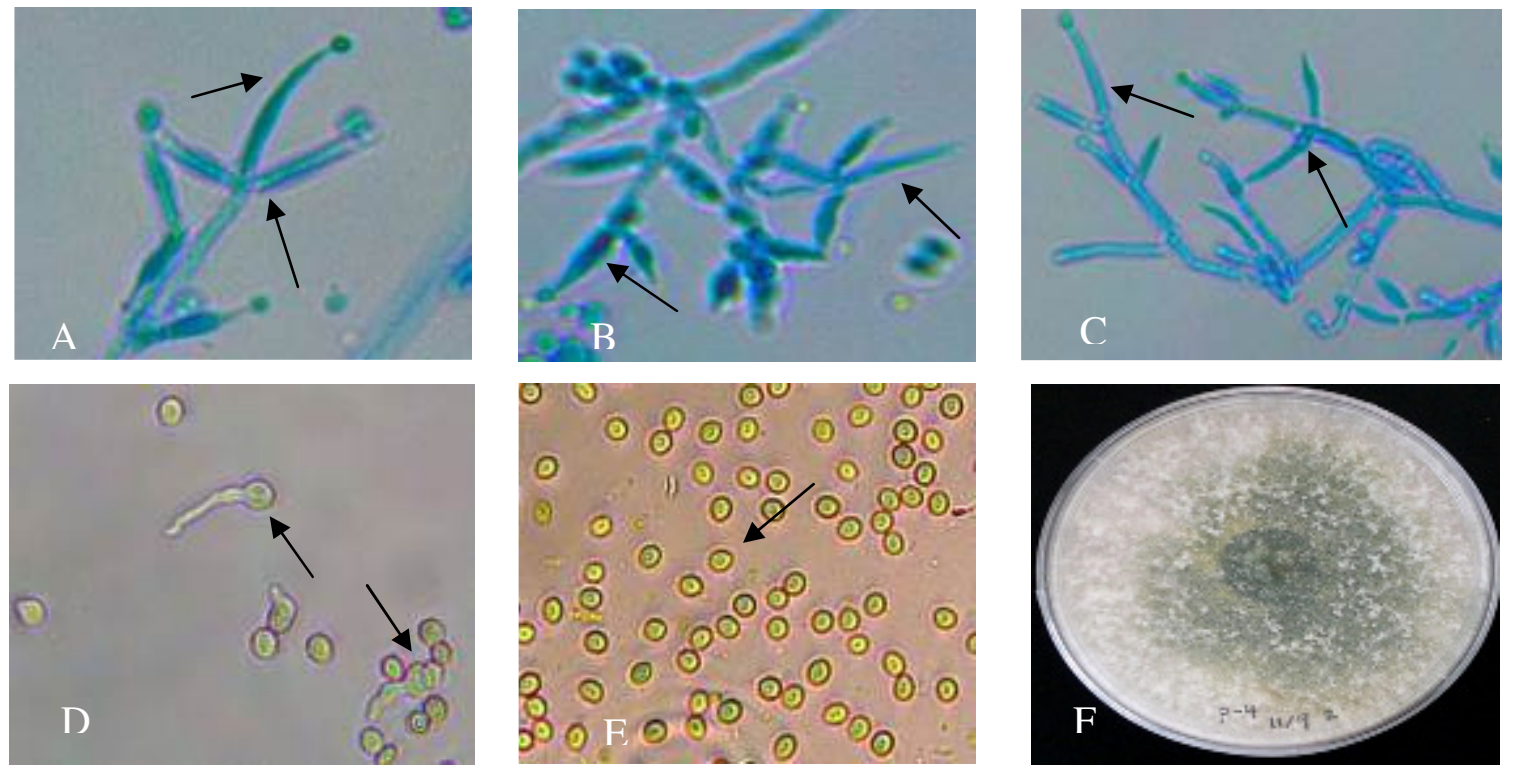

Figure 7. Morphological characteristics of T. viride isolated colony P12 (TVP12). A-C: The Phialides and the branches of conidiophores (arrows); D: Chlamydospores (arrows); E: Phialospores (arrow). F: Conidiation of Trichoderma viride on PDA plate. (Under microscope Leica: 40X).

\section{Trichoderma parareesei}

The isolated colonies EG6 and EG7 on macro-morphological and micro-morphological feature showed as $T$. parareese $i$. The conidia of colonies E6 or E7 appeared yellowish green in colour, uniformly ellipsoid, and smooth structure when observed (Figure 8A). The conidia, conidiophores, and phialides of Trichoderma parareesei are modestly similar to Trichoderma reesei because they came from the same ancestry group. Nevertheless, the conidiophores structure of Trichoderma parareesei was longer and branching compare to Trichoderma reesei (Figure 8B), (ANTANASOVA et al., 2010). The conidiophore revealed narrow branching and branches that arise paired with conidiophores which are longer and the bases are sterile however fertile at the branches (Figure 8C). The conidiation of EG6 or EG7 are 
found predominantly effused and in an abundant form after fourth day of inoculation, thus they possessed rapid growth on the PDA media plates
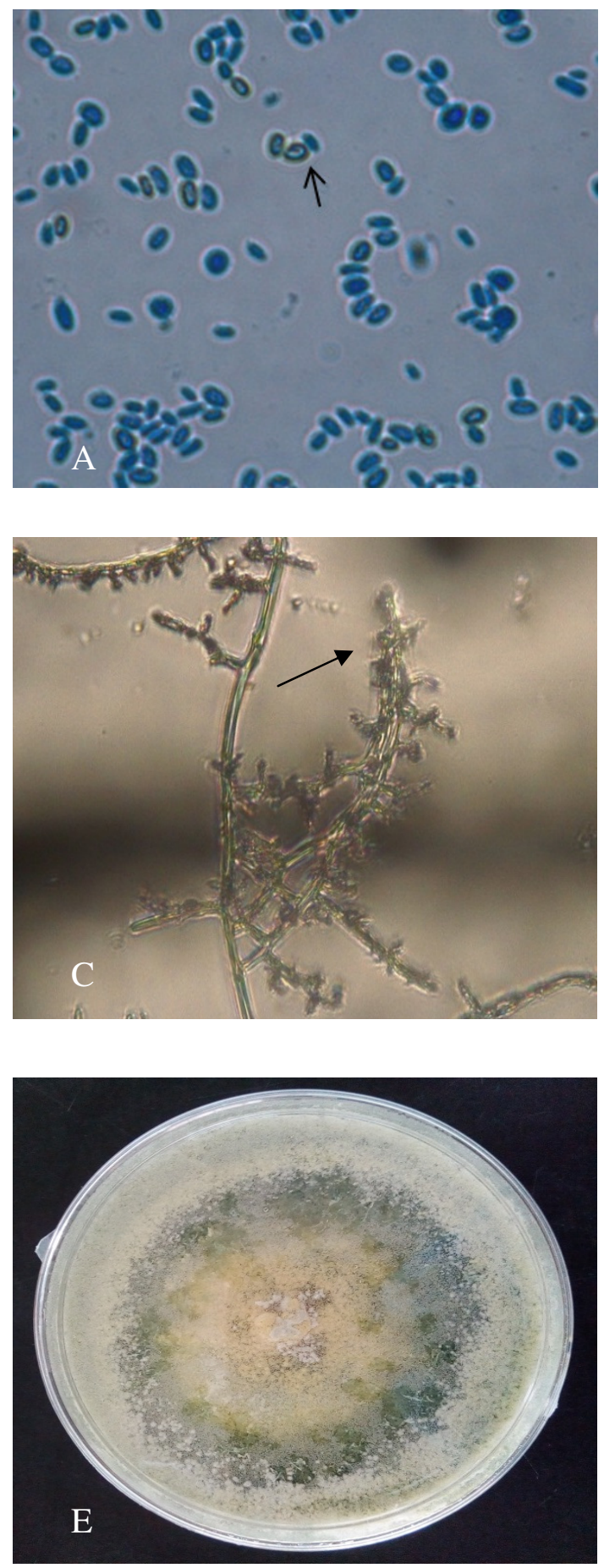

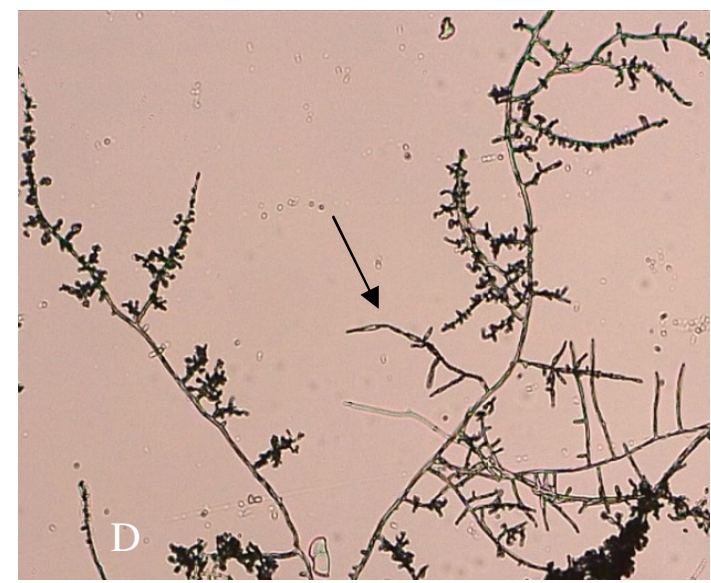

(Figure 8E). Based on these characteristics the colonies E6 and E7 refer as $T$. parareese $i$ coded as TPE6 and TPE7 (Table 2).
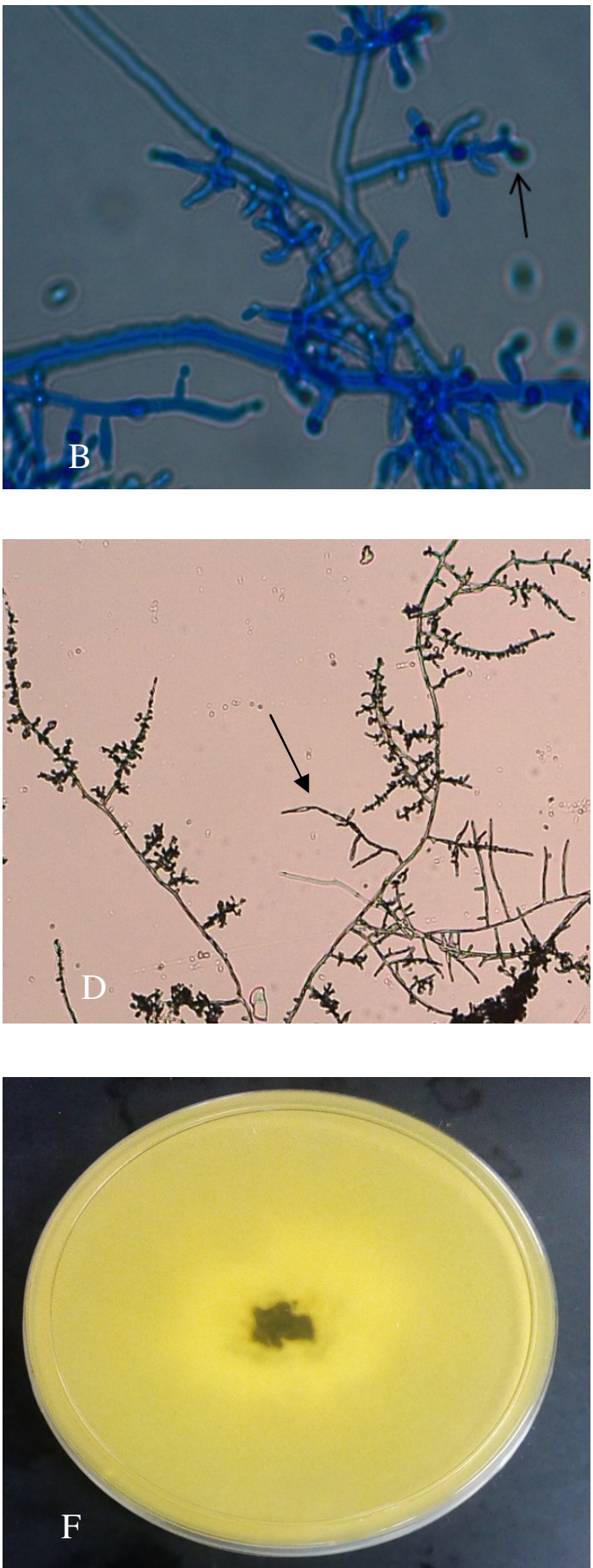

Figure 8. Morphological characteristics of T. parareesei colonies E6/E7 (TPE6 and TPE7). A: Conidia (arrow); B: Phialides (arrow); C: Conidiophores (arrow); D: Colony feature from front view on PDA; E: Bottom of PDA plate. Magnification: (Under microscope Leica: 40X).

Antagonistic activities of Trichoderma isolates against $F$. oxysporum

The antagonistic activities of Trichoderma isolates were tested against $F$. oxysporum on PDA at $25^{\circ} \mathrm{C}$ for 10 days. In all the dual culture plates tested, the contact zone was a curve, with concavity oriented towards the pathogenic fungi. The curvature of the contact area between the colony of antagonistic fungi and the pathogenic fungi is depend on the growth rate of colonies in the same plate. The curvature will be not occurred if the two colonies have same growth rate. In this study among 
the 16 isolates, the isolate colony E7, identified as Trichoderma parareesei strain TPE7 showed the strong highest antagonistic activity $91 \%$ against the F.oxysporum (Table3). The second highest antagonistic activity was $89 \%$ in same species (colony 6) T. parareesei strain TPE6 (Table3). The third highest antagonistic $76 \%$ found in colony LB4, identified as $T$. harzianum strain THLB4 (Table3). The rest of colonies found the antagonistic activities between the ranges $68 \%-74 \%$ except colony OP10 (T. virens strain TVOP10) shown in Table 3.

Table 3. Antagonistic activities of Trichoderma isolates against Fusarium oxysporum

\begin{tabular}{|c|c|c|}
\hline Isolate code & Trichoderma species & $\begin{array}{l}\text { Percentage of Antagonistic activity of } \\
\text { Trichoderma against } F \text {. oxysporum }\end{array}$ \\
\hline THPY1 & T. harzainum & 70.18 \\
\hline THPY2 & T. harzainum & 70.18 \\
\hline THS8 & T. harzainum & 68.18 \\
\hline THS9 & T. harzainum & 71.28 \\
\hline THLB4 & T. harzainum & 76.09 \\
\hline THLB5 & T. harzainum & 73.91 \\
\hline THT15 & T. harzainum & 74.34 \\
\hline THT16 & T. harzainum & 74.43 \\
\hline ТHB14 & T. harzainum & 71.57 \\
\hline TAPY3 & T. asperellum & 74.16 \\
\hline TVOP10 & T. virens & 58.7 \\
\hline TVR13 & T. virens & 73.17 \\
\hline TKOP11 & T.koningii & 71.40 \\
\hline TVP12 & T. viride & 70.65 \\
\hline TPE6 & T. parareesei & 89.13 \\
\hline TPE7 & & 91.0 \\
\hline
\end{tabular}

\section{DISCUSSION}

Biofungicide and biofertilizer for using the management of plant diseases are increasing in agriculture. The reason the biofungicide or biofertilizer control the disease in sustainable way and without any negative impact for the environment. In nature there are many microbial agents that cause disease in plant while some microbes are beneficial for plant. The genus of Trichoderma is one of beneficial fungus for plant that can found in soil. The species diversity is important for managing of phytopathogenic fungi. In this study different cultivated soils such as paddy, eggplant, tomato, oil palm, banana, rubber, were collected to isolate of Trichoderma species. The collected soils were culture on DRBC media to isolate Trichoderma colony from soil. Around 16 colonies showed the similarity feature of Trichoderma species (Table 1). Morphological identification of macro and micro studies identified six different species namely $T$. harzianum, $T$. virens, $T$. viride, T. asperellum, T. parareesei, and $T$. koningii. The colonies of PDY1,2; S8,9; LB4,5;T15,16 and B14 were dark green colour with dense white aerial mycelia formed on top of the plates. The conidiation was fertile pustules formation which a dense form of mycelia between 1 to $5 \mathrm{~mm}$ diameters formed giving a compact conidiophores (PLESSIS, 2015). GAMS; BISETT (2002) had stated that the Trichoderma harzianum formed a granular or powdery conidiation with a tuft or pustulates white fringes on plates Figure 2 (JL). Thus, these colonies identified as T. harzianum with strains as THP1, THP2, THS8, THS9, THLB4, LTLB5, THT15, THT16 and THB14. While the colony PDY3, refer as $T$. asperellum strain TAPD3 due to its colour formation. Trichoderma asperellum has been classified under clade Trichoderma paschybasium, it does not mean to have same characteristics with Trichoderma asperelloides which also from the same clade (PLESIS, 2015). $\mathrm{Wu}$ et al. (2017) had stated the morphology mycelium of Trichoderma asperellum was coarse and dark green conidia stated to form at the centre of the colony while, the Trichoderma asperelloides was showing smooth and dark green conidia under light microscope (WU et al., 2017). However, the colonies OP10 and R-13 identified as $T$. virens, refer as strain TVOP10 or R13 was relatively different from other Trichoderma isolates because the dull green colour only formed after four days of inoculation and the conidiation was loosely packed tuft (Figure 5F). The colony OP11 refer as $T$. 
koningii strain TKOP11, the colony at the commencement blue green to dull green sporulation (Figure 5F1 and 5F2) which similar with the finding of Shekhar et. al. (2017). The colony of OP12 the colour pigmentation was dark green which similar with T. viride. The colony E6,E7 refer as T.parareesei, dull pale green showed the similar findings of Shekhar et. al. (2017). Putty (2010) in his analysis state that Thrichoderma were producing various types of enzymes such as cellulases and chitinases which can give influences to the colour changes of mycelia during its growth (PUTTY, 2010). However, the green colour possesses by Trichoderma species can help researchers to identify and differentiate the Trichoderma species with other soil fungus easily while problem to differentiate between the Trichoderma species. Thus, anatomical or micromorphological studies on conidia, conidiophores, phialides, phialospore, chalamydosphores are very important to identification of Trichoderma species.

The conidia of Trichoderma harzianum can be differentiated from other Trichoderma isolates easily because the size were smaller and the colour were light green compare to Trichoderma asperellum and Trichoderma virens (SAVITHA; SRIRAM, 2015). In other situation, Trichoderma asperellum was similar with Trichoderma viride due to their warted structure but the conidia of Trichoderma asperellum was having less warted and more ovoidal than Trichoderma viride (SAMUEL et al, 1999).

In addition, the pattern of conidiophores and shapes of phialides were also the important key for identification. This is because some of species of Trichoderma formed different pattern and shapes of conidiophores and phialides. In this study, the colonies of PDY1,2;S 8,9; LB4,5; T15 and T16 were frequent branching conidiophores with more solitary phialides formed in whorls of 3 to 4 and mostly were ampulliform to lageniform at the dense area with 3 to 4 phialides (Figure 3; A-C) which refer as Trichoderma harzianum (GAMS; BISETT, 2002; PLESIS, 2015). Conidiophores of another isolates B14 (coded THB14) in species of Trichoderma harzianum was a verticillate pyramidal structure with nearly to $90^{\circ}$ angle of paired branched (Figure 3C). HUI (2013) reported that Trichoderma harzianum species possess solitary phialides which sometimes can be paired and unpaired in nearly $90^{\circ}$ to the main axis. The colony of PDY3 conidiophores were narrowly branching and the branches arise at pairs and unpaired along the main branches with the terminal conidiophores were more elongate than other (Figure 3; B-D). There were 2 to
3 phialides in pairs and shapes were divergent lageniform phialides which identified as $T$. asperellum. Apparently, the conidiophores in colony of OP10 and R13 were sterile at the base and have no branches but fertile at the end of conidiophores (Figure 5: A-B). The phialides were aggregate and closely appressed in 3 to 6 phialides (Figure 4: A) as similar pattern with $T$. virens. In colony OP11 the conidiophores formed from the main axis and branching occurred at nodes which diverged from the stipe at approximately right angles. Second degree branching were also observed bearing lageniform phialides (Figure 6: A-C). While, the conidia looked oblong and smooth-walled, these characteristics refer as T. koningii (Figure 6) similar with findings of PLESSIS (2015). The colony of P12 (coded TVP12) conidiophore narrow and flexuous with primary branches arising at regular intervals, mostly paired or in whorls of three (Figure 7; A-C). The phialides solitary, or 2-4 verticillate, more or less lageniform, often curved (Figure 7; AC) and the conidia was dark green, smooth, subglobose to obovoid as shown in Figure 7E. The different characteristics of this colony was it produced sweet coconut smell. Plessis (2015) reported that Trichoderma species produce distinctive coconut-like odours that belong to $T$. viride clade. In this research, this isolate P12 has a distinctive aromatic odour resembling coconut at fresh plate culture. GAMS; BISSETT (2002) also mentioned that the production of sweet coconut smell could be a characteristic of a species identification. Hence, the colony P12 identified as $T$. viride strainTVP12 (Figure 7). The colonies E6 and E7 (coded TPE6 and TPE7) appeared yellowish green in colour, uniformly ellipsoid, and smooth structure. Taxonomy characteristics found that Trichoderma parareesei occasionally secreted yellow pigment in the agar media due to production cellulase and variably superposed bright yellowgreen to dull green pustules which are similar to Trichoderma reesei (ATANASOVA et al., 2010). Thus, these colonies can be identified at $T$. parareesei. The conidia, conidiophores, and phialides of Trichoderma parareesei are modestly similar to Trichoderma reesei because they came from the same ancestry group. Nevertheless, the conidiophores structure of Trichoderma parareesei was longer and branching than Trichoderma reesei (Figure 8B), (ANTANASOVA et al., 2010).

Trichoderma is one of most primitive fungus that long been using as biocontrol agent, however, researcher are still isolating Trichoderma species for most and advance agent/strain for biocontrol (NAGLOT et al., 2015). To biocontrol 
study the plate assay technique is most suitable to identify promising agent at preliminary level. In this study among the 16 isolates, $T$. parareese $i$ both strains were highest as 91\% in strain TPE7 and 89\% in strain TPE6 (Table 3) showed antagonistic activity against $F$. oxysporum compare to $T$. harzianum, T. virens, T. koningii, and $T$. viride. Very few studies have been conducted to test biocontrol activity of $T$. parareesi, nevertheless, the study of Atanasova et al., (2010) reported that $T$. parareesi inhibited the growth of Lepidium sativum, the pathogen for garden cress. The beneficial effect of T.parareesei was observed against Pythium irregulare, Rhizoctonia solani, and Botrytis cinerea in plate assay as well as the interaction between T.parareesei and tomato plants (RUBIO et. al., 2014). Besides the control of these pathogen the fungus gave mutualistic relation in tomato plant to enhance lateral root development and enhanced Jasmonic acid defence gene expression in tomato plant (RUBIO et. al., 2014). The second highest antagonistic activity $76.09 \%$ was $T$. harizaum group in strain THLB4, while the others were in range 70$74 \%$ except $\mathrm{T}$. virens OPTV which showed $58.7 \%$ antagonistic activity in Table 3. The biocontrol activity might be differ based on the situation of pathogen and biocontrol agent. In this study T.parareesei showed the best promising species against Fusarium oxysporum.

\section{CONCLUSIONS}

Trichoderma are attractive fungal species in agriculture prospectus. The most talent point of this fungus is biocontrol potential, side by side mutualism in plant relationship especially enhanced plant development and plant defence immune. Thus, isolating of these fungus still on going to find which may reveal most promising biocontrol agent against versatile pyhtopathogen and might be potentially in industrial application.

Among the six different species the T.parareesei was exhibited most promising species against the phytopathogen of Fusarium oxysporum.

RESUMO: neste estudo foram isoladas seis espécies de trichoderma isoladas de solos rizosféricos de arrozais, bananeiras, dendezeiros, seringueiras, hortaliças e pastagens. As espécies são t. harzianum, t. viride, t. koningii, t. asperellum, and t. parareesei. O estudo morfológico como pigmentação, crescimento de colônias e estudos anatômicos como aparências de conidiação, tamanho de conídios, padrão de ramificação dos conidióforos, formas de phialides, ausência ou presença de clamidósporos foram realizados para identificar as espécies de trichoderma. As espécies de trichoderma harzianum foram abundantes no solo enquanto as de t. viren foram a segunda mais frequente no solo. Todas as espécies apresentaram atividade antagônica contra o fusarium oxysporum. Enquanto t. parareesei apresentou a maior atividade antagônica de 91,10\% contra f. oxysporum, relatado como melhor agente antagonista para fitopatógeno.

PALAVRAS-CHAVE: Atividade antagônica. Diversidade. Fusarium oxysporum. Trichoderma.

\section{REFERENCES}

ATANASOVA, L.; JAKLITSCH, W.M.; KOMON.,ZELAZOWSKA,. M.; KUBICEK, C.P.; DRUZHININA, I .S. 2010. Clonal species Trichoderma parareesei sp. nov. likely resembles the ancestor of the cellulose producer Hypocrea jecorina/T. reesei. Appl. Environ. Microbiol., v. 76, p. 7259-7267. 2010.

GAMS, W.; BISSETT, J. Morphology and identification of Trichoderma. In Christian, P. K., \& Gary, E. H. Trichoderma and Gliocladium Volume 1, Basic biology, taxonomy and genetics. Taylor and Francis London, p. 3-31, 2002.

HARMAN, G. E.; LORITO, M.; LYNCH, J. M. Uses of Trichoderma spp. to alleviate or remediate soil and water pollution. In (Lakskin, A. I., W. J. Bennett and G.M Gadd (eds.) Advances in Applied Microbiol., v. 56, p. 313-327. 2004. https://doi.org/10.1016/S0065-2164(04)56010-0

HUI, T. S. Morphological Characterization and sequence analysis of 5.8s-its region of trichoderma species. Bachelor Science. Thesis. University Tunku Abdul Rahman. Kuala Lumpur. 2013. 
NAGLOT, A.; GOSWAMI, S.; RAHMAN, I.; SHRIMALI, D.D.; KAMLESH, D.; YADAV, K.; VIKAS K. GUPTA, A., J., R., H. K. GOGOI, H. K.; VEER, V. Antagonistic potential of native Trichoderma viride strain against potent tea fungal pathogens in North East India. The plant Pathol. J., v. 31, p. 278-289. 2015. https://doi.org/10.5423/PPJ.OA.01.2015.0004

NAHER, L.; HO, C. L.; TAN, S. G.; YUSUF, U. K.; ABDULLAH, F. Cloning of transcripts encoding chitinases from Elaeis guineensis Jacq. and their expression profiles in response to fungal infections.

Physiolog. Molecul. Plant Pathol., v. 76, p. 96-103.2011.

NAHER, L.; ABDULLAH, F.; HO, C. L.; YUSUF, U. K.; TAN, S. G. Biocontrol agent Trichoderma harzianum strain FA1132 as an enhancer for oil palm growth. Pertanika J.Tropical Agricul. Sci., v. 35, p. 173-182. 2012.

NAHER, L.; YUSUF, U. K.; TAN, S. G.; SIQQIQUEE, S.; ISLAM, R. M. In vitro and In vivo Biocontrol Performance of Trichoderma harzianum Rifai on Ganoderma boninense Pat. Related to Pathogenicity on Oil Palm (Elaeis guineensis Jacq.). J. Pure Appl. pure Microbiol., v. 8, p. 973-978. 2014.

PLESSIS, I. L. D. The diversity of Trichoderma spp. in South Africa. Degree of Master of Science in the Faculty of Natural Sciences. Thesis. Stellenbosch University. 2015.

PUTTY, M. Trichoderma. Retrieved on 2017 from The Environment Reporter EM Lab websites: https://www.emlab.com/s/sampling/env-report-04-2010.html. 2010.

RAHMAN, M. M.; ALI, A. M.; ISLAM, M. M.; NAHER, L.; AHMAD, I. Evolution of disease development and potential biocontrol activity of Trichoderma sp. against Rhizoctonia solani on potato. Bioscience J., v. 30, p. 1008-1117. 2014.

RAHMAN, A.; BEGUM, M. F.; RAHMAN, M.; BARI, M. A.; ILIAS, G. N. M.; ALAM, M. F. Isolation and identification of Trichoderma species from different habitats and their use for bioconversion of solid waste. Turkey J. Biolog., v. 35, p. 183-194.2011.

RUBIO, B. M.; QUIJADA, M. N.; REREZ, E.; DOMINAGUEZ, S.; MONTE, E.; HERMOSA, R. Identifying Beneficial Qualities of Trichoderma parareesei for Plants. Appl. Environ. Microbiol., v. 6, p. 1864-1873. 2014. https://doi.org/10.1128/AEM.03375-13

SAVITHA, M. J.; SRIRAM, S. Morphological and molecular identification of Trichoderma isolates with biocontrol potential against Phytophthora blight in red pepper. Pest Managem. Horticul. Ecosyst., v. 21, p. 194-202.2015.

SEKHAR, C. Y.; AHMMED, K. S.; PRASAD, T. N. V. K. V.; DEVI, R. S. J. Identification of Trichoderma species based on morphological characters isolated from rhizosphere of groundnut (arachis hypogaea 1). Int. J. Sci. Environ., v. 6, p. 056-2063.2017.

SOYTONG, K. Identification of species of Chaetomium in Philippines and screening for their biocontrol properties against seed Born Fungi of rice. Ph.D. Thesis. Department Plant Pathology, ULPB, College, Laguna, Philippines. 1988.

VERMA, H. K. A Textbook of Fungi. Random Publication. New Delhi:India. p. 711. 2012.

ZHANG, N.; ZHANG, J. X.; RAZA, W.; YANG, X. M.; ZERUAN, Y.; SHEN, R.; HUANG, Q. W. Suppression of Fusarium wilt of banana with application of bio-organic fertilizers. Pedosphere, v. 24, p. 613624. 2014. https://doi.org/10.1016/S1002-0160(14)60047-3 